\title{
From Audio Branding to Sound Trademark: A Comparative Study in the EU and the US
}

\author{
Xinyu Zhang \\ Law School, Peking University, Beijing, China \\ Email: Christal34@yeah.net
}

How to cite this paper: Zhang, X. Y. (2021). From Audio Branding to Sound Trademark: A Comparative Study in the EU and the US. Beijing Law Review, 12, 409-424.

https://doi.org/10.4236/blr.2021.122023

Received: October 2, 2020

Accepted: April 23, 2021

Published: April 26, 2021

Copyright $\odot 2021$ by author(s) and Scientific Research Publishing Inc. This work is licensed under the Creative Commons Attribution International License (CC BY 4.0).

http://creativecommons.org/licenses/by/4.0/

\begin{abstract}
Audio branding generates high profit when it becomes a famous trademark, thus, the registration and protection of trademark is of great significance. The EU and US admitted sound trademark in advance. To analyze the criterion of registration in those two jurisdictions can provide useful legislative experience for the study of sound trademark. Based on the comparative study, we thus can identify critical factors which influence an audio branding becomes a sound trademark.
\end{abstract}

\section{Keywords}

Audio Branding, Registration, Sound Trademark

\section{Introduction}

Audio branding, as a relatively new concept, has been widely used in practice. Some acoustic designs have already become famous marks, for example, "the lion's roar of Metro-Goldwyn-Mayer" (US Trademark Reg. No. 1395550.), "the Nokia ringtone" (US Trademark Reg. No. 3288274), and Intel jingles. Behind those strong brands, high value and profit are generated beyond the product itself. Thus, the protection of brands' added value is of great significance. The trademark, as an exclusive right, is an effective tool to protect brands. In fact, the registration of sound marks has become an international tendency. Different jurisdictions, to a certain extent, specified the registration requirements in legislation. Audio designs need to meet the criteria before gaining the trademark protection. It is therefore quite critical to discuss the registration criteria.

In this essay, I discussed three aspects of sound marks. In first section, I made an introduction of audio branding, and then clarified the relationship between audio brands and sound trademarks. Next, I analyzed the major registration cri- 
teria of sound trademarks, for example, distinctiveness, functionality, representation, by reference to the EU and the US laws. Last, I made a quick look at the current legislation situation in terms of sound trademarks in other countries, and summarized the major limitations in legislation.

\section{The Distinction of Audio Branding}

Audio branding, or we can say sonic branding, includes related mechanism of recognition, information communication, image transfer and image consolidation, which uses sound to build up an emotional association between transmitter and receiver (Bronner \& Hirt, 2009). In other words, audio branding is the brand connected with acoustic design.

The terminology may seem new, however, "acoustic identities have been around for more than fifty years." (Ibid) As we all know, Big Ben, the great clock tower in Westminster, has become a notorious landmark of London. Whenever its low-pitched bells are used in TV shows or series, it just tries to release a signal that the story happens in London, not elsewhere. Dating back to the ancient times, specific music instruments were often associated with specific meanings. For example, trumpets were often used on religious and military occasions in ancient times. Its tone creates solemn atmospheres, and is easily for people to associate it with significant events. After frequent use, whenever the trumpet bells, people would realize that something serious happens. Messages could be transmitted by sound in such an impressive way, and this is what a modern company tries to deploy to create a relationship between acoustic logos and brand images in customers' minds.

Audio brand is often perceived as jingles, just as Keller defines, "jingles are musical messages written around the brand" (Keller, 2008). However, audio branding consists of more than one elements nowadays, in fact, it has developed a number of forms.

\subsection{Audio Logo}

The audio logo represents the sound mark of a brand and is often accompanies by a visual logo. (Ibid) A logo like this should be both precise and concise, so that the sound byte would be recognizable, memorable, and distinct. Just like McDonald's, it abstracted a short tune from Justin Timberlake's song "I'm loving it" as its sonic logo. It was sound in such an impressive way that acoustic logo completely showed its potential power. 93 percent of the people who were exposed to the McDonald's "I'm lovin' it" audio logo can recognize it. And also, it is the cornerstone of a global campaign, in which significant increasing has occurred since the start of the campaign (Franus, 2007).

\subsection{Brand Song}

Unlike a mere "commercial song used only temporarily for promotional purposes, a brand song is connected and attributed to the brand by regular and 
consistent use in brand communications and eventually becomes a real acoustic trademark." (Bronner \& Hirt, 2009). A brand song is not only used for adverting, but also is rooted in a company's culture. Take the example of Bon Jovi's song "It's my life", it was used as the theme song of the game CS. Since the song has a strong sense of rhythm, a hot-blooded lyrics, an enthusiastic melody, it is rather suitable used as a brand song for the game "Counter-Strike". Since It combines with the major features of this game, it perfectly motivates game players, and also draws the attention of those who are uninterested in the game initially. A brand song helps to reinforce the brand image in customers' minds.

Apart from the two major forms of audio branding, there are other elements could be used into sonic brands, like Brand Voice, Sound Icon, Sound Symbol, Corporate Anthem, and so on. There is no standard for a sonic brand. The elements of acoustic brand have a common trait. That is, we are emotionally affected by it, with our brand recognition increasing, without awaring of it and seeing it. (Ibid) However, before designing an audio brand which fits in the brand well, a company should first aware that, what the additional functions a sonic brand could serve compared with traditional brands?

\section{Audio Branding Functions}

\subsection{Effectiveness}

Traditional brands usually are expressed in a descriptive manner. Generally, the claims include short phrases, which has the use of communicating the brand identity visually. However, when it comes to music, the effectiveness of claims becomes more significant. (Ibid)

\section{1) Memorable}

Compared with descriptive expressions, music is full of rhythm and melody. The pattern of music could draw people's attention and strengthen the memory effect. Similarly, the intonation and rhythm of speeches takes the same function. In fact, sound is a natural tool used to convey emotions and messages. People would find it easier to remember the same thing when it is conveyed in an acoustic manner, or people have learned the brand song even before they access to the brand. Sonic brands just impress customers in this way.

\section{2) Distinctive}

Different rhythm patterns and melodies of music would make a brand sound more distinctive. Instead of expressing the brand in a silent way, brands conveyed in a piece of music or even a short sound byte would enable people to discern and distinguish them from massive choices more easily. "sound can immediately convey source-indicating qualities.” (Kahn, 1998). Designing a unique sound brand not only helps people memorize the brand name, but also helps people to recognize this brand even without seeing its logo. For example, the famous logo "I'm loving it". Whenever it sings, people know it would be McDonald's, rather than KFC. A sonic brand wins in this way. 


\subsection{Enhancement}

Apart from its semantic denotation, the acoustic pattern of a name could have a brand definition (Bronner \& Hirt, 2009). It is interesting to see the brand name such as "Crunchies", "Kitkat". Those brands imitate the sounds when we use its products, or the sound associated with the product. Such "phonetic devices in branding" (Keller, 2008) reinforce the relationships between the brand name and products, thus a name like "Kitkat" is not a meaningless word but a name closely related to its brand and product. A brand meaning is thus enhanced through sonic names.

Moreover, an audio branding also enables to enrich a brand. A brand expressed in a silent manner seems dull and ordinary, however, when set into a music, a brand is vitalized. Through acoustic expression, different rhythm and melody build different styles of brands. The brand culture, the company's goal, the targeted public, all these can be conveyed through its audio logo or brand song. A brand is not a static concept anymore, but has its own life and image. Three-dimension just becomes more popular to customers in the modern society.

\section{The Relationships between Brands and Trademarks}

When we summarize the functions of audio branding, we are discussing them in a context that the audio brands are protected by the law. That is to say, the right to use the audio brands should be exclusive, and should not to infringe or to be infringed by other parties. Along with the prosperity of audio branding, using intellectual property law to protect those brands becomes more essential and necessary. As a significant component of the IP law, trademark should be considered as an effective tool to protect the audio branding. However, before we figure out to what extent trademarks could protect brands, we should first examine the relationship between brands and trademarks.

According to the International Trademark Association (INTA): a brand is a mark which has acquired meanings above its functional use so that it can be distinguished from other traders (International Trade Mark Association). It is obvious to see that, brands gives the customers not only the product but also a value beyond the product (Davis, 2000). In this context, a brand's added value becomes a key issue. How to protect those added values should be the law's tasks.

Trademark rights are exclusive rights. They allow their owners to "exclude others from certain uses of the signs that constitute the subject matter of protection" (da Silva Lopes and Duguid, 2010). The most useful function of trademarks is the distinction function. It facilitates consumers to distinguish products from massive choices and enable enterprises to build a unique image in the market. That is to say, some competitors may try to produce the same goods and services, whereas trademarks could help to protect the brand of the origin company. And secondly, with trademarks, a company can also exist within its own right and can choose to transfer the goods or services independently (Aaker \& Joachimsthaler, 2000). 
Also, trademark is an effective way to protect or even improve brands' reputation. Consumers can trust the source indication and quality of goods and services with a mark because of the protection of trademarks from unauthorized use (Boulware and Baker McKenzie LLP). In fact, it has become a trend that more and more non-traditional trademarks, such as sound trademarks, are available for registration in different jurisdictions as long as they fulfill the law requirements.

\section{Registration of Sound Trademark}

A trademark is a kind of sign indicating that the goods and services are different from others (Hart et al., 2009). Traditionally, We can get knowledge of information from the use of brand names, logos, or symbol adorning goods and services by trademarks (Thomas Mccarthy, 2004; Landes \& Posner, 1988). And there are indeed about 106,000 trademarks applications (Bronner \& Hirt, 2009) at the Office for Harmonization in the Internal Market (OHIM) (OHIM Annual Report, 2011), in which most of the Community Trademarks are formed by word marks (60.79\%) and figurative marks (38.39\%) (Statistics on Community Trade Marks, 2012). However, trademarks in today's world are not as simple as that in the past. With the development of modern technology, two-dimensional marks are no longer the major methods to build a brand image, instead, a sophisticated society needs more creative elements involved into brands to enhance their distinctiveness. Non-traditional marks, which consist of creative multi-sensory designs, gradually invade traditional marks' market position. Just like the sound trademark, it has already become a popular method used by companies to attract the customers.

A sound mark is a trademark whose function is performed by sound, identifying the commercial origin of products or services (Wikipedia, 2006). Or it could just be defined as "identify[ing] and distinguish[ing] a product or service through audio rather than visual means" by the Trademark Rule of Examining Procedure 1202.15 (The Trademark Rule of Examining Procedure 1202.15).

\subsection{General Requirements for Registration}

The Agreement on Trade-Related Aspects of Intellectual Property Rights (TRIPS) is an international agreement, which is administered by the World Trade Organization (WTO). It makes the minimum standards for all countries belonging to the WTO (TRIPS Art. 1(3)). According to the article 15, TRIPs gives a general definition for a trademark, "any sign, or any combination of signs, capable of distinguishing the goods and services of one undertaking from those of other undertakings, must be eligible for registration as a trademark, provided that it is visually perceptible." (TRIPS Art. 15). In article 25.1 of the TRIPS Agreement, it also states the general protection for industrial designs (TRIPS Art. 25 (1)).

We can summarize some general principles from the articles mentioned above: A trademark which is eligible for registration should at least pass three tests: 1) 
Distinctiveness 2) Representation 3) Functionality. Many Intellectual Property (IP) Regulations are formed based on the general principles, however, member countries of WTO do have their own freedom to determine specific requirements. In this essay, we majorly take the example of EU and US laws.

\subsection{Comparative Studies of Distinctiveness Standards}

Distinctiveness is the first requirement for registration and also the primary function of a trademark. The function of distinctiveness is the origin of a brand. There are massive choices of products in the market. To build a memorable market image and obtain an advanced market position, companies use brands to distinguish their own products from other products. Those brands which are registered as trademarks are protected by the law, that is to say, trademark law protects brands' distinctiveness and prevents unfair competition.

It is therefore that, a sound trademark needs to demonstrate its distinctiveness initially before registration. However, the question is, what's the criteria to assess distinctiveness? In fact, different jurisdictions have different answers to this questions, and we should treat differently depending on the counties concerned.

1) Regulations in the EU

The main instruments of European trade mark law are Council Regulation (EC) 207/2009 of 26 February 2009 on the Community trade mark (hereinafter referred to as the "CTMR") and Directive 2008/95/EC of 22 October 2008 to approximate the laws of the Member States relating to trade marks (hereinafter referred to as the "Directive") (Troussel \& Meuwissen, 2012).

In the European Union, an open mind is held towards sound trademarks. In fact, the broaden legal definition just provides chances for any non-conventional signs to be registered as trademarks as long as they fulfill the criterions. According to the Directive, Art 2, "any sign capable of being represented graphically... provided that such signs are capable of distinguishing the goods or services of one undertaking from those of other undertakings" (Article 4, CTMR and Article 2 of the Directive). It is clear that, the scope of registration encompasses sound signs. The thing that needs to do first is to demonstrate the sound marks' distinctiveness.

Although there is no evident expression in terms of non-traditional marks in EU Directive, in application, according to EU settled case law, we could identify the general criteria EU courts used to assess distinctiveness. In Case of HAG II, distinctiveness was explained that "the origin of the product bearing the sign to the consumer or final user, allowing him/her to distinguish, without any likelihood of confusion, this product from those of a different origin." (Case C-10/89, HAG II, 1990, ECR I-03711, 14, later confirmed in numerous cases like Case C-349/95 Loendersloot, 1997, paragraph 24 and Case C-39/97, Canon Kabushiki Kaisha v Metro-Goldwyn-Mayer Inc., 1998, ECR I-5507, paragraph 28).

Further, the general rule of determining distinctiveness could also be that, "(i) by reference to the goods or services in respect of which registration has been 
applied for and (ii) in relation to the perception of the relevant public" (Case C-473/01Procter \&Gamble v OHIM, 2004, ECR I-5173; Case C-25/05 P, Storck v OHIM, 2006, ECR I-5719; Case C-144/06, Henkel v OHIM, 2007, ECR I-8109).

From these rules mentioned above, we could summarize three key criterions to assess the distinctiveness in EU case law: First, An empirical assessment is necessary (Findings of the CJEU, 2011; Lindt \& Sprüngli v OHIM, 2012)1. For example, a test to consumers. Assumptions and decisions should be verified by data. The test may be more strict to non-traditional trademarks because those signs may need more evidences to demonstrate their distinctiveness, however, it should be equally applied to all marks in this category, including sound trademarks. Second, at least a significant proportion of consumers could successfully distinguish it from other signs (Case C-265/09 P, 2010). Although a minimum degree of distinctiveness is commonly accepted, the trade mark also has to be distinctive in the European Union as a whole, allowing for being able to be distinctive as a community trade mark; (Guidelines for Examination in the Office, 2015) Third, the sign should avoid the likelihood of confusion to the public. That is to say, the sign should avoid similarities to other previously registered or famous trademarks. The Sabel case has listed the criterion of "likelihood of confusion, including the likelihood of association with earlier mark" (Case C-251/95, Sabel BV v Puma AG. See also Case C-342/97). In order to assess the likelihood of confusion, it depends on whether we could recognize the trade mark of the market, the combination with the used and registered sign, how similar the trademarks and the signs are and how similar the goods and services identified are (Case C-251/95, Sabel BV v Puma AG, para. 9. See also $10^{\text {th }}$ Recital-Harmonisation Directive). Those similarities may include "phonetic similarity, visual similarity and similarity of meaning" (About the evaluation of confusion, see Franzosi, pp. 300-318). Any similarities which may trigger difficulties for consumers to identify the sign from others damages trademarks' distinctiveness.

2) Regulations in the US

In the United States, although it also gives no expressly recognition of sound trademarks in its trademark law, (Lanham Act $\$ 45,15$ U.S.C. 1127, 2000)² some regulations do have clear interpretations for sound trademarks. Sound marks may be registered if they are used in commerce and have capacity to distinguish. (Lanham Act $\$ 1,15$ U.S.C. $\$ 1051$ (a) (1), 2002) Lanham Act states that "any word, name symbol or device" that is used on or in connection with some good or service may be registered if it has secondary meaning (Lanham Act $\$ 1,15$ U.S.C. $\$ 1051$ (a) (1), 2002) $)^{3}$. According to The Trademark Trial and Appeal

\footnotetext{
${ }^{1}$ Findings of the CJEU: "It must be noted that the requirement to carry out an a priori examination of the distinctive character of a sign does not preclude that examination being based on the facts.". ${ }^{2}$ The Lanham Act defines a trademark as any word, name, symbol, or device, or any combination thereof-[which is] used by a person, or which a person has a bona fide intention to use in commerce and applies to register.., to identify and distinguish his or her goods, including a unique product, from those manufactured or sold by others and to indicate the source of the goods, even if that source is unknown.

3“The owner of a trademark used in commerce may request registration of its trademark...".
} 
Board (TTAB) (TTAB, 1978), sound trademarks could be divided into two categories: inherent distinctive or non-inherently distinctive marks ${ }^{4}$. Put it an easier way, a sound which is originally unique may need no proof of second meaning, however, if it is not inherent distinctive, sounds that are commonplace would need evidence of secondary meaning to prove that they acquire distinctiveness (TTAB, 1978) .

\section{3) Second Meaning}

Second meaning is often obtained through frequent use, and that's the reason why it is usually referred to as "acquired meaning". According to the Wal-Mart Stores, Inc. v. Samara Bros., Inc., 529 U.S. 205, 211 (2000), “Secondary meaning refers to a mark's actual ability to trigger in consumers' minds a link between a product or service and the source of that product or service. That is, a mark has secondary meaning 'when, in the minds of the public, the primary significance of a mark is to identify the source of the product rather than the product itself."' (TTAB, 1978).

In the famous sound mark case, General Electric applied the sound of ship's bell clock to radio broadcast services ${ }^{6}$. The Board studied the usual sounds and those arbitrary, unique, or distinctive sounds, and finally discovered that the sound of ship's bell clock is the one that mostly conforms the requirements.

Apart from the second meaning test, Confusion test is another effective tool to assess distinctiveness. The US court also listed a set of factors used to identify confusingly similar trademarks, like the actual confusion existing between the trademarks, similar appearance, sound and meaning of the trademarks, and so on $^{7}$ (In re E.I. du Pont de Nemours \& Co., 476 F.2d 1357 (CCPA 1973)).

Although the standards for assessing distinctiveness seem sophisticated and strict, there are still numerous sound marks passing the strict tests and successfully registered as trademarks in US. Some of them has become famous in the worldwide. For example, "the lion's roar of Metro-Goldwyn-Mayer" (US Trade${ }^{4}$ The Board noted that "unlike the case of a trademark which is applied to the goods in such a manner as to create a visual and lasting impression upon a purchaser or prospective purchaser encountering the mark in the marketplace, a sound mark depends upon aural perception of the listener which may be as fleeting as the sound itself unless, of course, the sound is so inherently different or distinctive that it attaches to the subliminal mind of the listener to be awakened when heard and to be associated with the source or event with which it is struck."

${ }^{5}$ (Stating that a sound may be "unique, different or distinctive," i.e. inherently distinctive, or commonplace, requiring secondary meaning for registration). See also Midge Hyman and Hannah Chung, Registration and Enforceability of Non-Traditional Trademarks in the United States.

${ }^{6}$ The mark was described in the application as "a series of bells tolled during four, hour sequences, beginning with one ring at approximately a first half hour and increasing in number by one ring at approximately each half hour thereafter." Id. The application was submitted with an audio tape recording of the sound. Id. at 562.

${ }^{7}$ Whether the two trademarks are confusingly similar depends on a number of factors, including: 1) The existence of actual confusion in the marketplace between the trademarks; 2) Similarity of the appearance, sound and meaning of the trademarks; 3) Similarity of the goods and services being identified by the trademarks; 4) The degree of secondary meaning acquired by the trademarks; 5) The sophistication of the consumers who buy the particular products or services; 6) The similarity of the channels of distribution of the products or services (that is, are they both sold in the same types of stores); 7) The degree of commercial competition between the two trademark users. 
mark Reg. No. 1395550), "the Nokia ringtone, consisting of a classical guitar score (US Trademark Reg. No. 3288274) played worldwide 1.8 billion times a day" (Treasure, 2009; Oliveira v. Frito Lay Inc., 58 U.S.P.Q. 2d 1767 (2d Cir. 2001)).

\subsection{Comparative Studies of Functionality Standards}

We can take sounds as trademarks, but we must know the difference of using it as a function and as goods itself (Oliveira v. Frito Lay Inc., 58 U.S.P.Q. 2d 1767 (2d Cir.2001)). Doctrine of Functionality was originated from the US, and was developed to eliminate the adverse effects of unfair competition. A trademark shall not be protected if its design is essential to this category of product, because once functional trademarks are registered as exclusive rights, it would significantly restrict others from producing goods which require the same design. The rationalisation here is to guarantee that the functional design is free to every market participants so that a sound market competition could be established. The functionality doctrine makes it possible for a producer to control a useful product feature. Thus, it can protect trademark law from inhibiting legitimate competition. The trademark law is aiming at promoting competition by protecting the reputation of a firm (See Qualitex Co. v. Jacobsen Products Co., Inc., 514 U.S. 159 (1995)).

As an imperative requirement for trademarks, the functionality doctrine has almost been adopted by all jurisdictions. Trademarks which have passed the strict test for distinctiveness have a further hurdle to cross before registration. In fact, a trademark will not be registered if it includes functional designs no matter how distinctive it is. And it has been displayed clearly in EU and US trademark laws.

\section{1) Regulations in the EU}

"Article 7 (1) (e) CTMR excludes registration of the signs which consist exclusively of: i. the shape which results from the nature of the goods themselves; ii. the shape of goods which is necessary to obtain a technical result; iii. the shape which gives substantial value to the goods." (Article 7(1) (e) CTMR).

The wording of this provision seems refer more to the shape of the sign, however, article 7 (1) (e) CRMR does not confine to any single type of signs. It makes no difference between traditional or non-traditional trademarks. It must be held that Article 7 (1) (e) CTMR may apply to trademarks reproducing shapes, regardless of the dimension in which they are represented (Judgement of 08/05/2012, T-331/10).

We also use the assessment scope of this provision in sound trademark. If we can conclude that one of the criteria of the provision is included, according to the Article 7 (1) (e) CTMR, we don't need to address whether the sign has acquired distinctiveness through use, because by invoking Article 7 (3) CTMR, we cannot overcome the objection under Article 7 (1) (e) CTMR (Judgement of 06/10/2011, T-508/08). 


\section{2) Regulations in the US}

Same like the EU, US also has a test for examining the functionality. According to "the US Patent \& Trademark Office's (PTO) TMEP 1202.02 (a) (v) instructs trademark examiners to consider the following four criteria when analysing whether the subject matter is functional with respect to the goods: 1) Whether there exists a utility patent that discloses the utilitarian advantages of the design sought to be registered; 2) Whether there is advertising by the applicant that "touts the utilitarian advantages of the design"; 3) Facts pertaining to the availability of alternative designs; and 4) Facts pertaining to whether the design results from a comparatively simple or inexpensive method of manufacture." (The US Patent \& Trademark Office's (PTO) TMEP 1202.02 (a) (v)).

Case law is the effective way to see how the rules apply in practice. In terms of sound trademark, there is a famous case in US we should not overlook. In Kawasaki Motors Corp., USA v. H-D Michigan Inc., Harley-Davidson is a company started in a Milwaukee in 1903. It produces Motorcycles and has become a successful enterprise in US. In fact, Harley-Davidson has litigated numerous trademark infringement suits in US, much of them has been successful (HarleyDavidson, 1994a; Harley-Davidson, 1994b). On February 1, 1994, Harley-Davidson applied registration for the sound of its motorcycles. Harley-Davidson illustrated this sound as "potato-potato-potato", and also slowly, over and over (Dejonge, 1996; Pisarsky, 2008). However, Nine of Harley Davidson's competitors, like Suzuki, Yamaha, opposed against the registrability of Harley's trademark (O'Dell, 1996). The reason for subjection was that, the motorcycle sound engine used for this style of motor cycle just sounds identical to Harley's. The key issue is not about whether Harley's sound design has acquired distinctiveness or second meaning, but is that its sound design fell into the functional scope.

Harley's demonstrated that trademark is a function of its V-Twin, common crankpin engine design. And this is important to the "use or purpose" of the motorcycle (Sapherstein). Instead applying the sound design as a patent, Harley Davidson attempted to take the trademark law as an umbrella, and get a patentlike monopoly when designing the engine technology ${ }^{8}$. This behaviour violated functionality rule in trademark law. Trademarking a functional design would prohibit other manufacturers to produce the same engine which sounds like Harley's design, and this would damage the sound competition environment in the motorcycle market.

Harley failed to pass the functionality test, no matter how hardworking it tried to prove its sound design had acquired distinctiveness. After six years waiting, Harley eventually abandoned its application. And the final outcome would be: "Harley's competitors will continue building motorcycles with common crankpin V-Twin engines, and any infringement lawsuits will likely be unsuccessful" (Sapherstein).

${ }^{8}$ The distinctiveness of the trademarks means that, are they descriptive or are they arbitrary and fanciful. 


\subsection{Comparative Studies of Representation Standards}

\section{1) Regulations in the EU}

According to the Directive, Art 2, "any sign capable of being represented graphically... provided that such signs are capable of distinguishing the goods or services of one undertaking from those of other undertakings", (Article 4, CTMR and Article 2 of the Directive) it is clear that a sound trademark should be able to be graphic presented. Sound marks which consist exclusively of descriptive signs do not conform to the requirements of art.2 Directive and also art.4 CTMR.

The EU law required strictly for graphic representation. Graphic representation enables applicants to define a sound mark precisely by using music notes, thus the authorities or the public could ascertain the scope of trademark protection clearly ${ }^{9}$ (Sieckmann, 2003). In order to achieve such an object, that searchers can readily ascertain what is registered and to determine infringement rights when checking the registry ${ }^{10}$, (Hidaka et al., 2004) the EU not only requires the "principle of precision" (Case C-49/02, Heidelberger Bauchemie GmbH, 2004 E.T.M.R. 99, 13), but also need to provide legal certainty and accessibility (Survey conducted by Managing Intellectual Property, 2004).

These was confirmed in the case of Shield Mark BV v. Joost Kist (case C283/01) the E.C.J. In this case, "it confirmed the registrability of sound marks in the EU, provided that sound is distinctive and able to be represented graphically" (Shield Mark, 2004). The E.C.J. requires graphic representation by "means of images, lines or characters, so that the mark can be precisely identified" (Sieckmann, 2003), and also to be "clear, precise, self-contained, easily accessible, intelligible, durable and objective." (Shield Mark, 2004) ${ }^{11}$. If a sound mark consists of music, the Office will accept traditional musical notation as a graphic representation of the sound applied for ${ }^{12}$ (Shield Mark, 2004).

A mere description of the sound in words is not sufficient. (R 708/2006-4, "TARZAN YELL") A sound trademark which couldn't be depicted will not be admitted by EU's law. It may find easily for a piece of music, a tune to be registered as a sound trademark, however, sonograms were not allowed to registered as sound trademarks before 2005. Noises, slogans, spoken words cannot be graphically represented by musical notation (Roth, 2005-2006). The Fourth Board of Appeals' (Board) in Metro-Goldwyn-Mayer Lion Corp's Application found that, a sonogram could also satisfy the requirements of graphic representation, but it just uses different method to be depicted. (Ibid)In fact, the graphic representation of a sonogram is "superior to that of musical notation, since more nuances and, in particular, sound characteristics are depicted." (Case R-781/

\footnotetext{
${ }^{9}$ Ascertaining the scope of protection is important to each of these groups for different reasons. Trademark holders must be able to determine whether a new mark will infringe its rights, a competitor needs to know what it can or cannot do without triggering an infringement action, and consumers need to know how far they can extend their reliance on the source.

10“'The policy behind this decision was to enable people checking the trade marks register to be clear about what is registered given the paper nature of the registry.".

${ }^{11}$ The graphic representation must be self-contained, easily accessible, and intelligible so that users of the registry can determine the precise nature of the mark.

${ }^{12}$ In accordance with the criteria of the judgement of 27/11/2003, C-283/01, "Shield Mark".
} 
1999-4, 2004). Thus, a non-musical sound could be registered as musical marks.

Meanwhile, Article 6 (3) of the Implementation Regulation of the CTMR now provides for that electronic sound files can be filed together with the sound mark application (Troussel \& Meuwissen, 2012). A sonogram or an oscillogram will be acceptable if the graphic representation is accompanied by a corresponding sound file submitted via e-filing ${ }^{13}$. The problem that certain types of sounds are not capable of being graphic represented by musical notations could thus be solved in this way.

\section{2) Regulations in the US}

Different from the EU, in the U.S., it does not need a drawing as to the registration of sound, scent, and other invisible marks, but a detailed description of the mark is needed (37 C.F.R. $\$ 2.52$ (e) (2003); T.M.E.P., $\$ \$ 807.09,1202.13$, 1202.15.). Graphic representation has times when visual record fails to depict sound precisely. The reason why description is so important may be that, "A description is desirable] [ $\mathrm{t}$ ] o make sure that others are aware of the nature and salient features of a mark." (Hawes \& Dwight, 2004). Besides, description also facilitates searchers to look for the registered marks by the key features described rather than by the graphic picture only. Not everyone has the ability to understand music notes or sonograms.

To guarantee the precision of the description, T.M.E.P. also requires that when explaining the description, it must be accurate and precise, with no misleading impression of the mark (37 C.F.R. $\$ 2.52$ (e) (2003); T.M.E.P., $\$ \$ 807.09,1202.13$, 1202.15.). Like Netbytel, Inc., Reg. No. 2788028, “The mark consists of a xylophone tone, playing a series of $16^{\text {th }}$ notes, beginning at middle 'C': CECDCFDG."; or the case of "the sound of the famous Tarzan yell" (Edgar Rice Burroughs, Inc., Reg. No. 2210506), the mark was described in a very detailed and specific way ${ }^{14}$.

Apart from the description requirements, audio recording is also needed especially when the sound is vague to be described. The description is primarily to help the PTO fill and refer the mark properly....when meeting difficulties in identifying the letters and numbers included, the descriptions are of help (Hawes $\&$ Dwight, supra note $90, \$ 3.20)$. A combination of musical score and description provides better records of sound marks.

\section{The Future of Sound Trademarks}

Sounds have become an important method used to help consumers better recognize and distinguish brands and products. Behind the famous audio branding,

${ }^{13}$ See decision of the President EX-05-3 of 10/10/2005.

${ }^{14}$ “'The mark was described as a yell consisting of a series of approximately ten sounds, alternating between the chest and falsetto registers of the voice, as follow[s]: 1) a semi-long sound in the chest register, 2) a short sound up an interval of one octave plus a fifth from the preceding sound, 3) a short sound down a Major 3rd from the preceding sound, 4) a short sound up a Major 3rd from the preceding sound, 5) a long sound down one octave plus a Major 3rd from the preceding sound, 6) a short sound up one octave from the preceding sound, 7) a short sound up a Major 3rd from the preceding sound, 8) a short sound down a Major 3rd from the preceding sound, 9) a short sound up a Major 3rd from the preceding sound, 10) a long sound down an octave plus a fifth from the preceding sound." 
massive profit can be generated by those sound marks. It's the law's role to protect the added value of a sound mark. Indeed, different jurisdictions have already recognized the current situation and made an amendment in their laws.

In March 2006, the Singapore Treaty on the Law of Trademarks was adopted by 147 WIPO Member States in Singapore, then entered into force on March 16, 2009. This Treaty set out a multilateral framework for the law definition of different types of marks which included non-visible signs on trademark application and registration. In its last two sessions, according to the SCT (the WIPO Standing Committee on the Law of Trademarks), there are some areas representing and describing non-traditional marks being defined, like 3D marks and sound marks (Non-Traditional Marks, 2009). It was meaningful in that this was the first international reference discussing non-traditional marks in that area.

China also revised its Trademark Law in August 30, 2013, and the new law has been implemented on May 1, 2014 (Eight things you need to know about the new Trademark Law, 2013). Amongst the amendments, the most significant one is that the revised law extended non-traditional trademark registration to cover sound. Although the relevant examination procedure is waited to release, it is still an important progress for China to keep pace with international standards, and provide an enhanced protection for businesses.

The Japan Patent Office began to receive applications for non-traditional trademarks on April 1, 2015 after the trademark law was revised in 2014, and announced its first registration of sound marks on 27 October, 2015 (New trademarks issued for sounds, 2015). Among the 43 new trademarks, 21 were sound ones. Those include a melody singing the name of Hisamitsu Pharmaceutical Co. and a special way calling out the name of a tea product of Ito En Ltd. (Ibid)

Although protecting the sound trademarks has become an international tendency, the law in terms of sound marks still need to be enhanced. In European countries, tackling with sound marks relied heavily on case law, and lack of corresponding regulations. In fact, not only in EU, but also in Asia countries, for efficacy of these revised laws, we now need to set an explicit regulations which governs the registration, or we could not fulfill the objective behind (Smell and Sound Marks to be Introduced, Marinade Concerning Asia, 2012).

\section{Conclusion}

In modern times, the world is full of brands with high-tech designs. The audio mark, as a popular technical method, has consisted of an important part to establish a distinguished brand; meanwhile the trademark law serves an essential function to protect those audio brands. By analyzing of the EU and the US laws, we could summarize the core criteria that an audio brand need to meet the distinctiveness and functionality standards, and should be able to be graphic presented. And also, those rules established meaningful models to other jurisdictions. However, current legislations are still immature, and many counties haven't admitted the sound trademark yet. The audio branding, as well as the sound 
trademark, still has a long way to go.

\section{Conflicts of Interest}

The author declares no conflicts of interest regarding the publication of this paper.

\section{References}

37 C.F.R. $\$ 2.52($ e) (2003); T.M.E.P., $\$ \$ 807.09,1202.13,1202.15$.

Aaker, D. A., \& Joachimsthaler, E. (2000). The Brand Relationship Spectrum: The Key to the Brand Architecture Challenge. California Management Review, 42, 8-23.

About the Evaluation of Confusion, see Franzosi, 300-318.

Article 4, CTMR and Article 2 of the Directive.

Article 7(1) (e) CTMR.

Boulware, M. A., \& Baker McKenzie LLP. Emerging Protection for Non-Traditional Trademarks: Product Packaging and Design.

Bronner, K., \& Hirt, R. (2009). Audio Branding: Brands, Sound and Communication. Baden-Baden: Nomos, Edition Reinhard Fischer.

Case C-10/89, HAG II [1990], ECR I-03711, 14.

Case C-144/06, Henkel v OHIM, [2007], ECR I-8109. Judgement of 08/05/2012, T-331/10, 'Surface covered with black dots', para. 24.

Case C-25/05 P, Storck v OHIM, [2006], ECR I-5719.

Case C-251/95, Sabel BV v Puma AG, para. 9. See also 10th Recital-Harmonisation Directive.

Case C-251/95, Sabel BV v Puma AG. See also Case C-342/97.Case C-251/95, Sabel BV v Puma AG. See also Case C-342/97, Lloyd Schuhfabrik Meyer \& Co. GmbH v Klijsen Handel BV9.

Case C-265/09 P, OHIM v Borco, [2010] ECR I-08265, See Paragraphs 42 and 44: "[the OHIM] Argues That the Average Consumer Is a Legal Concept and That the Examination of the Distinctive Character of a Sign Must Be Carried Out Independently of Any Actual Use of That Sign on the Market.

Case C-473/01Procter \&Gamble v OHIM, [2004], ECR I-5173.

Case C-49/02, Heidelberger Bauchemie GmbH, 2004 E.T.M.R. 99, 13.

Case C-98/11 P, Lindt \& Sprüngli v OHIM, [2012], paragraph 47.

Case R-781/1999-4, 2004 E.T.M.R. 34.

da Silva Lopes, T., \& Duguid, P. (2010). Trademarks, Brands, and Competitiveness. Routledge International Studies in Business History.

Davis, S. M. (2000). Brand Asset Management Summary and Analysis (pp. 97-123). June 9th.

Dejonge, J. (1996). Harley Seeks Protection for Its "Spudly" Sound: Distinctive Motorcycle Engine Revs Up Trademark Concerns. The Seattle Times, March 28.

Edgar Rice Burroughs, Inc., Reg. No. 2210506.

Eight Things You Need to Know about the New Trademark Law, China Law \& Practice, Nov, 2013.

Findings of the CJEU:"It Must Be Noted That the Requirement to Carry Out a Priori Examination of the Distinctive Character of a Sign Does Not Preclude That Examina- 
tion Being Based on the Facts." Case T-508/08, Bang \& Olufsen v OHIM, [2011], paragraph 71 .

Franus, N. (2007). Building Brand Value through the Strategic Use of Sound. AIGA. org. http://www.aiga.org/content.cfm/building-brand-value-through-sound

Harley-Davidson, Inc. v. Selectra International Designs, 861 F.Supp. 754, 754 (E.D. Wis. 1994b).

Harley-Davidson, Inc. v. William Morris D/B/A Bill's Custom Cycles, 19 F.3d 142, 142 (3d Cir. 1994a).

Hart, T., Fazzani, L., \& Clark, S. (2009). Intellectual Property Law (5th ed., Chapter 8, p. 79). London: Palgrave Macmillan.

Hawes \& Dwight, Supra Note 90, $\$ 3.20$.

Hawes, J., \& Dwight, A. (2004). Practitioner's Trademark Manual of Examining Procedure $\$$ 808.01.

Hidaka, S. et al. (2004). A Sign of the Times? A Review of Key Trade Mark Decisions of the European Court of Justice and Their Impact upon National Trade Mark Jurisprudence in the EU. The Trademark Reporter, 94, 1105-1124.

In re E.I. du Pont de Nemours \& Co., 476 F.2d 1357 (CCPA 1973). U.S. Trademark Reg. No. 1395550.

International Trade Mark Association. https://www.inta.org

Judgement of 06/10/2011, T-508/08, “Representation of a loudspeaker”, para. 44.

Kahn, E. W. (1998). On the Net, Unusual Marks Gain in Importance, the National Reporter $C-13$.

Kawasaki Motors Corp., U.S.A. v. H-D Michigan Inc., 43 U.S.P.Q. 2d 1521 (TTAB 1997.).

Keller, K. L. (2008). Strategic Brand Management. 164.

Landes, W. M., \& Posner, R. A. (1988). The Economics of Trademark Law. The Trademark Reporter, 78, 267-270. (explaining "SANKA designates a decaffeinated coffee made by General Foods Corp.; XEROX the dry copiers made by Xerox Corporation.... A stylized penguin is the symbol of a line of paperback books published by Penguin Books... ").

Lanham Act $\$ 45,15$ U.S.C. 1127 (2000).

New Trademarks Issued for Sounds (2015). Movements under Revised Law. The Japan Times News, Oct. 28.

Non-Traditional Marks-Singapore Treaty Enters into Force. WIPO Magazine, February, 2009. http://www.wipo.int/wipo magazine/en/2009/01/article 0002.html

O’Dell, J. (1996). Trademark Rumble: Rivals Fight Harley’s Claim to Sound. Los Angeles Times, March 30, at B1.

OHIM Annual Report 2011. http://oami.europa.eu/annualReport 2011/pdf/AnnualReport 2011_EN.pdf

Oliveira v. Frito Lay Inc., 58 U.S.P.Q. 2d 1767 (2d Cir.2001).

Pisarsky, N. (2008). NOTE: PoTAYto-PoTAHto-Let's Call the Whole Thing Off Trademark Protection of Product Sounds. Connecticut Law Review, 40, 797-806.

Qualitex Co. v. Jacobsen Products Co., Inc., 514 U.S. 159 (1995).

Roth, M. E. (2005-2006). Something Old, Something New, Something Borrowed, Something Blue: A New Tradition in Non-Traditional in Non-Traditional Trademark Registrations. Cardozo Law Review, 27, 457.

Sapherstein, M. B. The Trademark Registrability of the Harley-Davidson Roar: A Multi- 
media Analysis. Boston College Intellectual Property \& Technology Forum.

Shield Mark, 2004 E.T.M.R. 33, T 55.

Sieckmann (2003). E.T.M.R. 37, 91 48-49, 51. Ascertaining the Scope of Protection Is Important to Each of These Groups for Different Reasons.

Smell and Sound Marks to Be Introduced, Marinade Concerning Asia, 21 August, 2012.

Statistics on Community Trade Marks, 2012.

http://oami.europa.eu/ows/rw/pages/OHIM/statistics.en.do

Survey Conducted by Managing Intellectual Property. The Truth about Trade Marks, Managing Intell. PROP., May 2004, at 32.

The Trademark Rule of Examining Procedure 1202.15.

The US Patent \& Trademark Office's (PTO) TMEP 1202.02 (a) (v).

The Wal-Mart Stores, Inc. v. Samara Bros., Inc., 529 U.S. 205, 211, $\mathrm{n}^{\star}(2000)$.

Thomas Mccarthy, J. (2004). Trademarks and Unfair Competition S 2:3 (4th ed.).

Treasure, J. (2009). The 4 Ways Sound Affects Us.

http://www.ted.com/talks/julian treasure the 4 ways sound affects us.html

TRIPS Art. 1(3).

TRIPS Art. 1, 15, 25.

TRIPS Art. 25(1).

Troussel, J.-C., \& Meuwissen, S. (2012). Because Consumers Do Actually Eat Trade Marks: An Assessment of Current Law Regarding Non-Conventional Trade Marks in the European Union. ERA Forum, 13, 423-438. https://doi.org/10.1007/s12027-012-0272-x

TTAB (1978). In re General Electric Broadcasting Co., Inc., 199 U.S.P.Q. 560.

U.S. Trademark Reg. No. 3288274.

Wikipedia (2006). Sound Trademark.

https://en.wikipedia.org/wiki/Sound trademark\#cite note-1 